\title{
团之 部
}

\section{1 蘇聠考察榢在古代芘加那區 域發現古蹟}

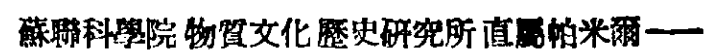
斐加郱考察的七個粗，已於去年十一月底返抵列察格

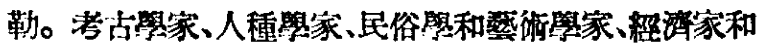
建築做們，在七個月中跋涉了六千公里。

科學家們的洘察在韯加那人民交化史上開始了有 趣的新頁。在古代的斐加那首都尼希城淮行發掘.工作

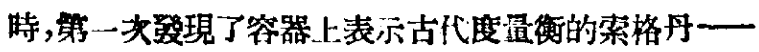

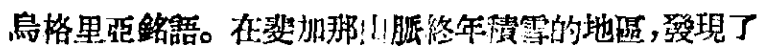

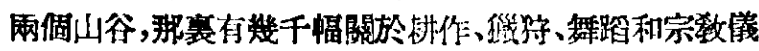

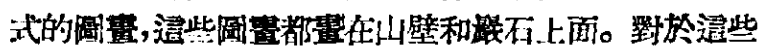

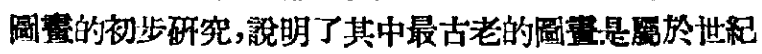
前二:千年到三千年的。

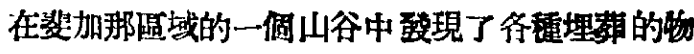
件:制、七首、陶器、銅鏡等。

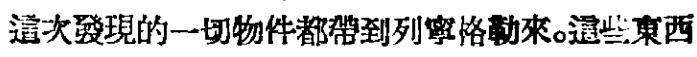
在這襄將受到多方面的科登研究。

(新華社稿1950.12.5.)

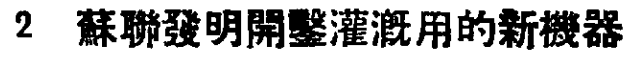

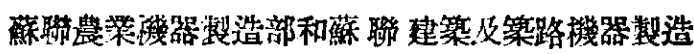

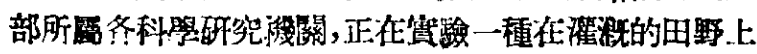

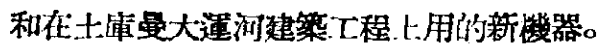

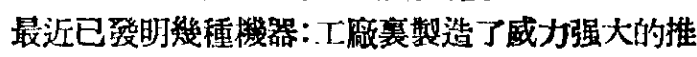
土機, 每架的機器,都好㡜是一塊带有黎板和顿斜着安 .t的刀的大龬板。鋼板按設在拖拉機的前面，藉助推士 機來㙞塞㴖渠和经地，削平土地，上的丘陵起伏的地段。

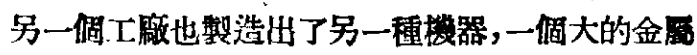
年運斗，容量達六立方公尺以上，固定在有兩根軸的鐵

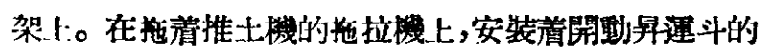

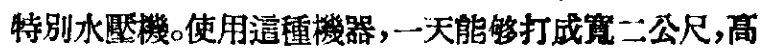
一公尺和長 150 公人以上的堤医。

第三種機器, 是新的挖䉿機也已創造出來, 它安設

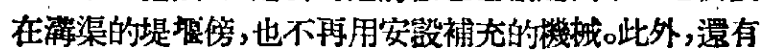
一種移植樹木的自動起重機, 也可在引水渠和灌啭渠的 兩岸,栽植樹木了。 (缜理報)

\section{3 蘇聯慜造控制氣候的機器}

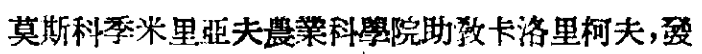

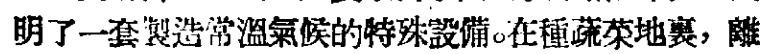

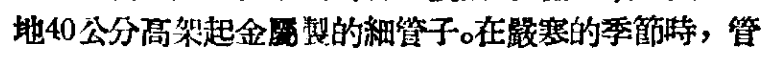

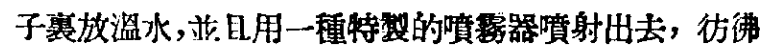

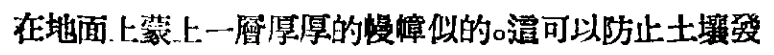
散溫度。度之, 在资热的天氣赛, 則在管子寒放冾水, 噴 射出去後可以在炎炎的烈日下保護植物。

(華果農林 1 很 5 期)

\section{4 '罾光'一禁聯最新式盲人 用打字機}

凡是見滑伐文打字機的人，都知道上面有四小次個

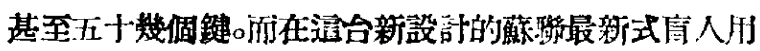
打字機上: 却谨谨有六個，但奇怪的是不見天日的目人們

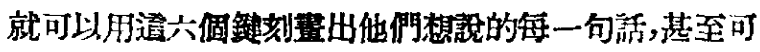
以打.上.他要用的 '!’。

這合宣人用打字機的器機結棬非常簡單，它没有鉛 字,只有六個排成兩行的小圆棍, 在目人的摸索之下问

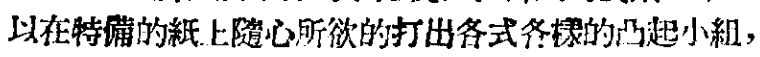

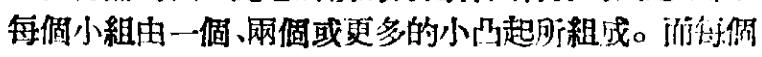

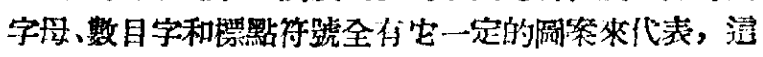

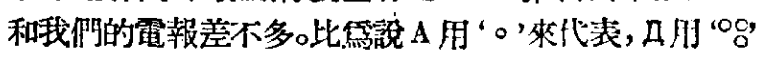
來代表, 逗兩個闾婪相鄰的打在一起就組成 盟 字A Д (地獄)。很多的單字組織在一起便成了句子, 成了交音。

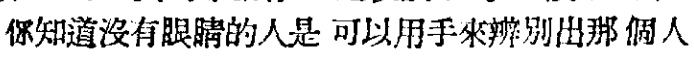
是與他相識的，那個人是陌生的。同栐打那筑能的手他

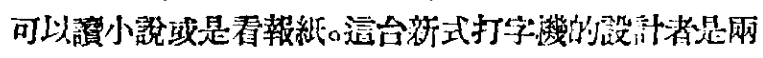

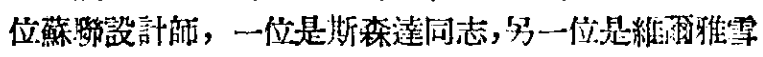

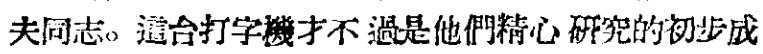
就,但就結橾和其他备方面來說, 比很多外國名牌的序 人用打字機要儤越的多了。

在伎用外國名牌的宗人用打字機的時候，经用打的

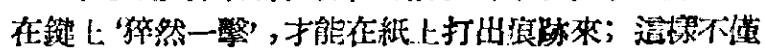

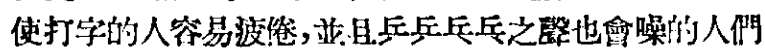

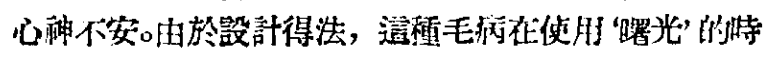
是完全可以避化的。此外在问英製或法製的機子，上寒 紙侍還須用很大的力氣才能做到, 因此打出来的行列也 就不會整就了。而 ‘䁌光” 就能把那些左三右回的點子排

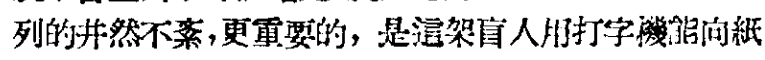

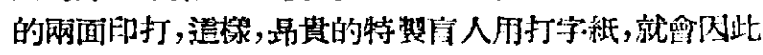

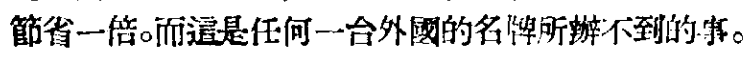

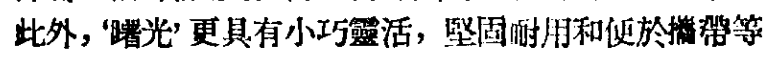
缘點。

（聚北中蘚友好No.81）

\section{5 菻聯機車上的信號燈}

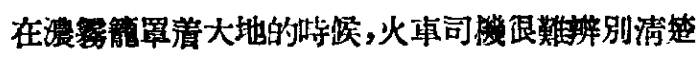

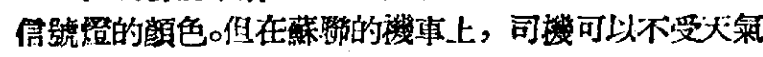

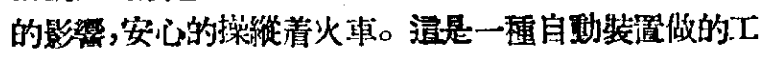

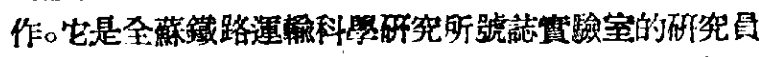

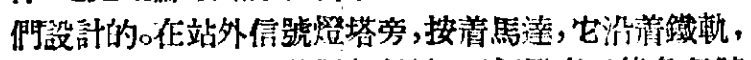

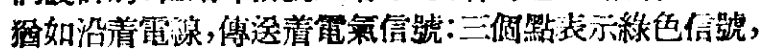
兩個點一一黃色信號，一個繁——紅色信號。

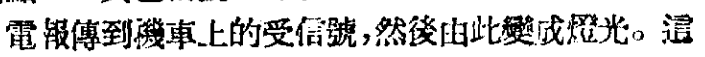

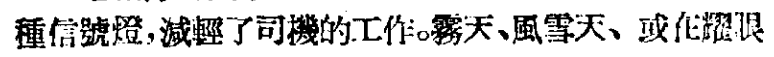

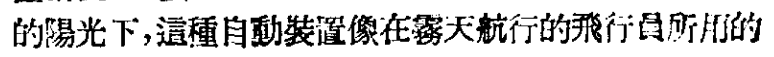
器栈一琭,能助勘制別方向。(果北中蕉反好No.31) 


\section{6 地下勘察器}

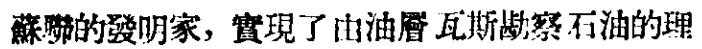
想,科學家和工程師共同没計了一種感檫很强的工具, 造種.工具秪要根挜地下油層中的瓦斯運行, 便可以探察

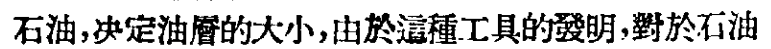
的探垛方面,貢链了很大的便利。

(蘇聯瓷料No.2)

\section{7 能自由活的人造手瞥}

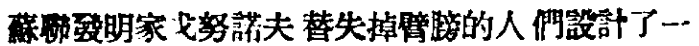

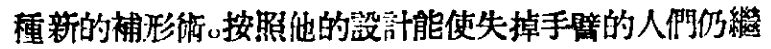
儥织事勞動, 並目可以作各種動作, 包括用機栰的泊指

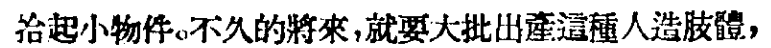

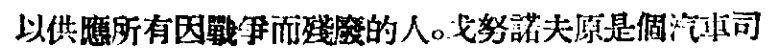

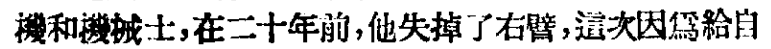
已設計假右暨，竟然成了一個發明家。由於他不湔意在

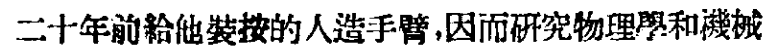

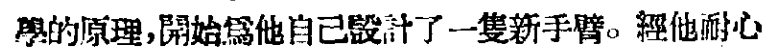

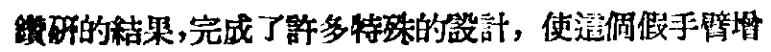

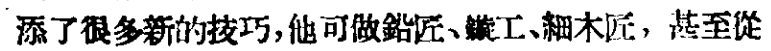

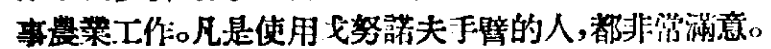

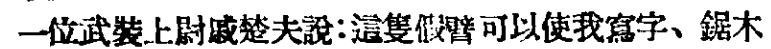

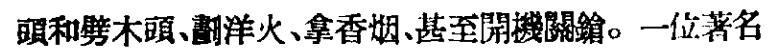

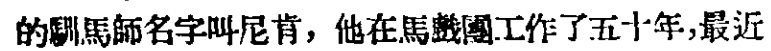

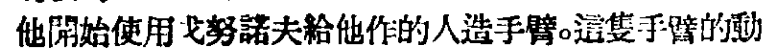

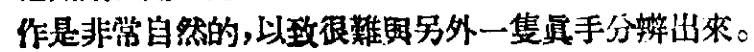

（萑漛資料No.7）

\section{8 蕉的亞熱带科學研究所在中 亞細亞寞䮦種植暮樹}

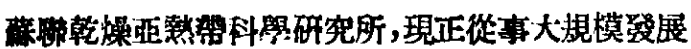

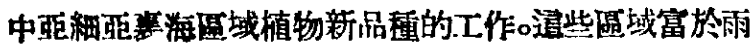

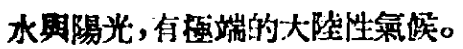

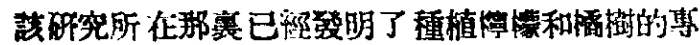
門方法: 把樹木璉在夏天管水流冬天繁霜的一程特別的

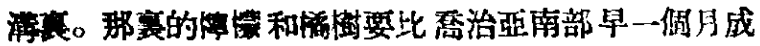
然。研究所的工人們在中亞細亞種植生出乳狀液计的照

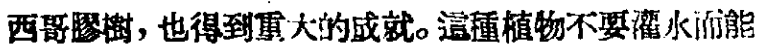
種植,在垃界上還是第一次。

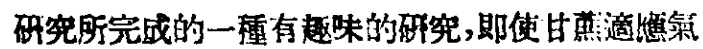

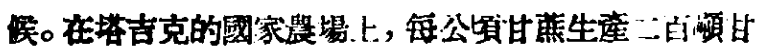

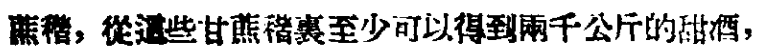
进此英國甘蕉地的重量多二倍牛。

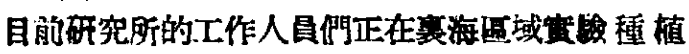

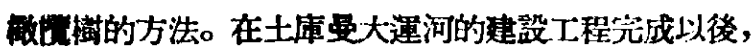

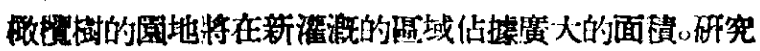

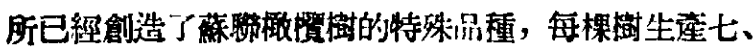

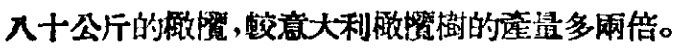

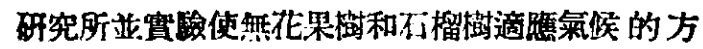

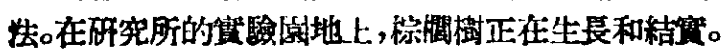

(新華社檍 1950.12.7.)

\section{9 烏克荡科學家養助水力建設}

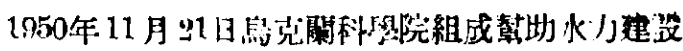

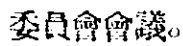

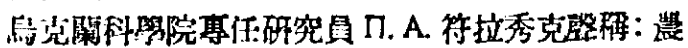

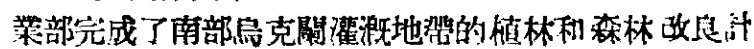
㙕的基礎工作。現在曟業部正研究着播種面樍和對灌活 豊的輪種制之構成問題。

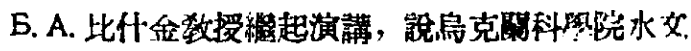

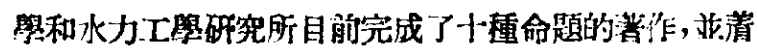

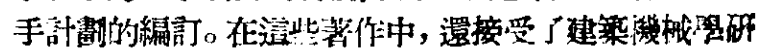

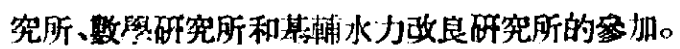

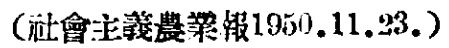

\section{0 二十座新的水力弡龟站}

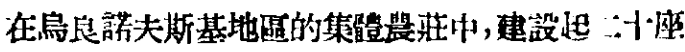
新的水力發電站。

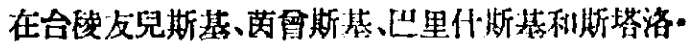

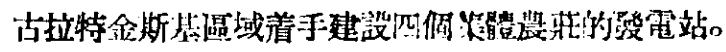

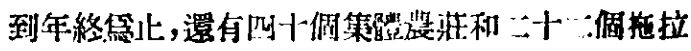

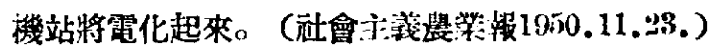

\section{1 哈刺·庫姆考察圈}

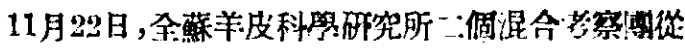

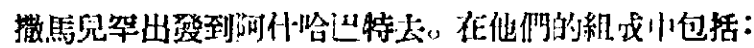

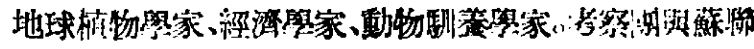

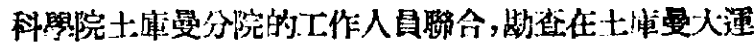

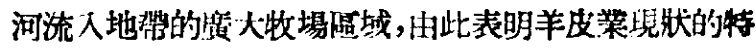

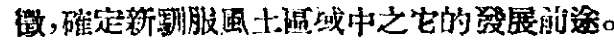

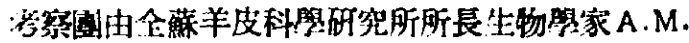

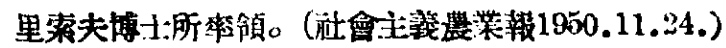

\section{2 塔吉克科學院成立}

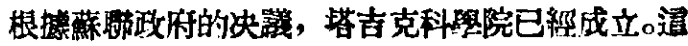
是在蘚維埃政權時代条加盟共和國中成立的第十一储

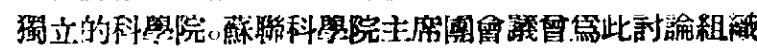

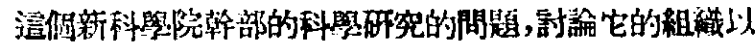

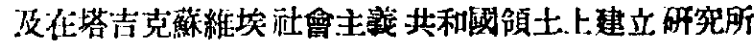
網的問題。

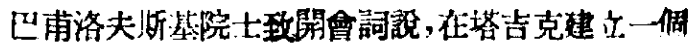

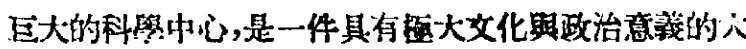
事。

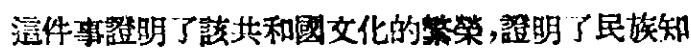
識分子幹部的増長。

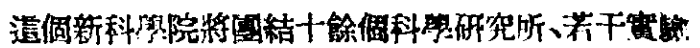
站、一個氣象台和帕米爾山、的一個高山植物洛、該科

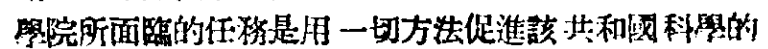

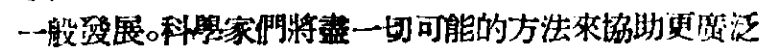

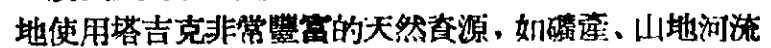
的電力源泉:宜於椒培棉花與最有僧值的水渠作物的土。

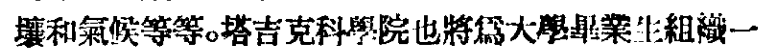
倜特別研究所, 訓蝶青年科學幹部。 
荅吉克共黨 (布爾什維克) 中央委員會書記加伏

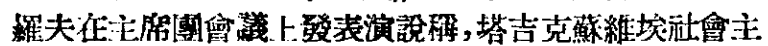
義共和國科學院的成立也是俄纙斯科學家的一大成就。 他們封助塔皆克人民在共和國內設立了很多科祭研究

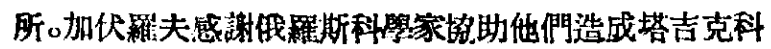
學眀文化的繁榮。（新華社稿1950.11.21.）

\section{3 蘇聯植物學會 (BEO)}

該會理事會於 1949 年 1 月 7 日開會通過新會員名 單58人。今年 1 月29日至30日在列密格勒舉行全體代表

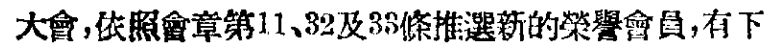
列著名的植物學家當選: (1) 李森科、(2)影洛得科夫(B. Н. Городков) 、(3)歐派林 (А. И. Опарин)、(4)拉斯 多爾斯基 (Б. Ф. Раздорский)、(5) 索斯諾夫斯基 (Д И. Сосновский)。

該會蔡行有植物學䆶誌 (БотаническийЖурнал) 脽月刊，今年已出至三十然然，其內容有專著、簡報、書

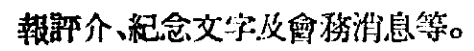

(中國植物學雜誌5管 1 期)

\section{4 蘇聯畜産家出席科學會議}

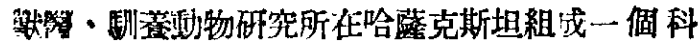

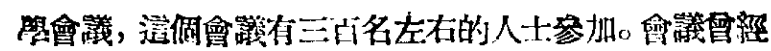

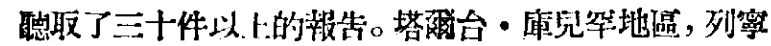

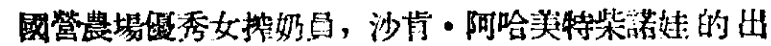

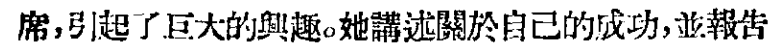
自己的維驗。去年, 阿哈莫特柴誶娃同志從她所管的入 隻牝牛中的每一隻,能够揣出牛奶 5680 公斤。在今年十

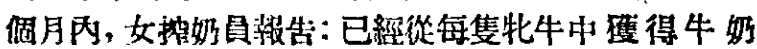
5. 影松厅。

科照家们娸高采烈地㮩取了阿爾馬・阿丁地温、札 姆布爾澡、阿活格爾台集體堎馬場管理員，社會主哦勞

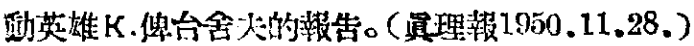

\section{5 蘇聯米邱林斯克城舉行墢展 果樹會議}

在倬大的自然改造者米邱林的證生地一-D米邱林

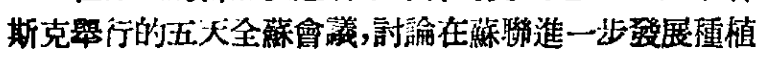
綶樹的工工作。

在戰後幾年間,集體農場果澍国的面債增加了十四

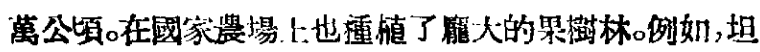

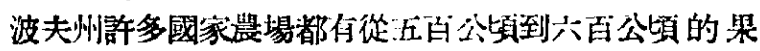

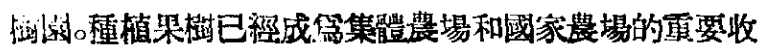
人的緸灣部門了。

在莫斯科、列察格勒、伊风墸伏和其它工業中心的

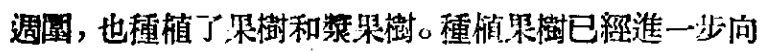

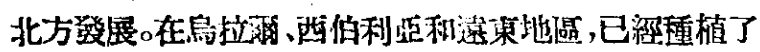
幾百處果樹林。種植栥樹得到各處實騟站、科學研究所 的巨大堼㘦。單在米邱林斯克一地就有幾個逗㮔機關。

葆聯科學家們已經擬召了一一個計劃, 在伏爾加河和 第垂伯河跘，及沿着士庫曼大運河及克里米丝運河的水 力發電站的噪域,種植六百公頃到一千公頃的果樹林。
在以後幾年內,薪眑冬州果樹林的面啧將增加六借 到八倍。

（新華社稿1950,12,19）

\section{6 蘇聯派遗代表出席甸牙利科 學院紀念會}

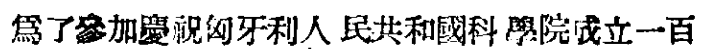
二十五週年紀念會，蘚聯科累院在 10 月 24 日派遗由 M.M.杜比尼內院士所率領的科路家代表楝赴布達佩 斯。

代表團人選包括：К.и。斯克留平院士、史孟博士

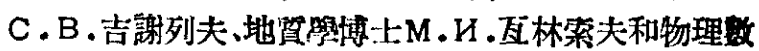
照博士K.K.馬爾查尼什維里。(猉理報1950.11.25.)

\section{7 蘇聯紀念俄羅斯偉大病理學家 伊凡諾夫斯基逝世三十週年}

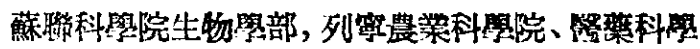

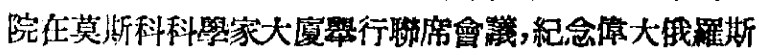
科䀢家伊凡諾夫斯基逝浽三十週年。

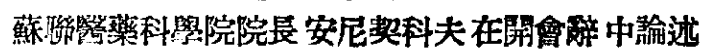

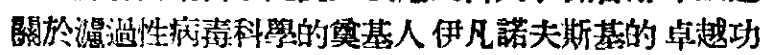
精。科學院院-上馬克西莫夫、薢聯科祭院通訊院士李日 科失和其他人等,在報告中叙述了伊凡諾夫斯基的生本

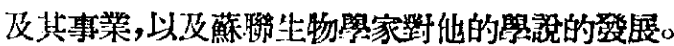

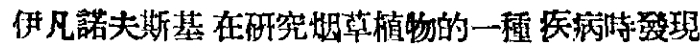
了诲過性病表表。伊凡諾夫斯基在1892年發表的“關於烟 草植物网種疾病啲科學著作腹立了新的知識部門— 病瑇科學。逪程弹現證明了對克服傳染病具有無比的重 要性，蓝使俄國在知識的新领域內建立了倡先性:。現今 人們都知道，人類和動植物身．上有二百多種疾病都是從 病毒起源的。

五十多年前伊凡諾夫斯基所閏明的科學原則,促淮

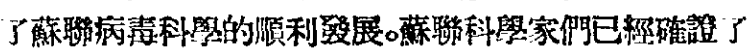

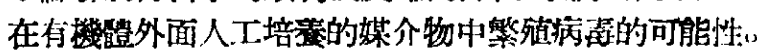

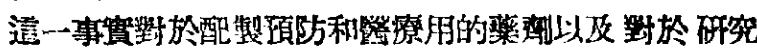
病毒都具有特别巨大的重要性。

蘇聯科學家所確定的微生物存在於發展各階 段的

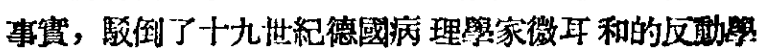

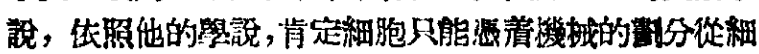

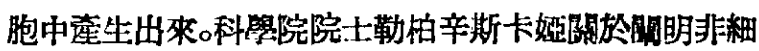

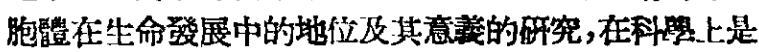
一種最重大的事件。

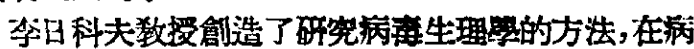

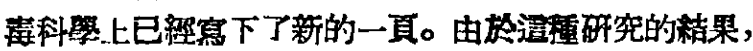
已經發現了若干物暂能够制止傳染病的病毒的繁殖。曾

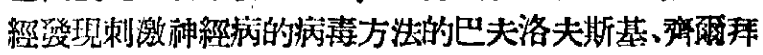
爾、楚默科夫和其他敎授等的渚作，均已馳名拟界。

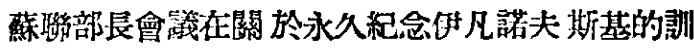

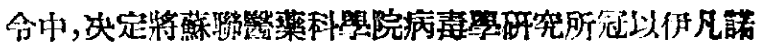

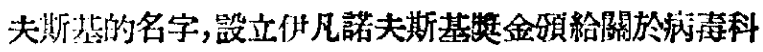
奇的最保唀的作品，並在1951年出版他的選集。

(新華社稳1450.11.28.)
第一期

科學通報 


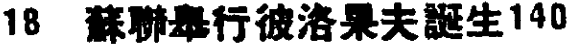 摁年級念}

1950年10月25日是俄國卢越的外科祭學家彼洛果

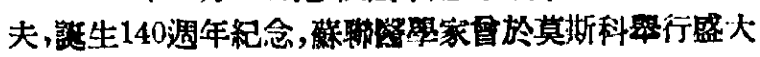
的埗念會。

(正理報)

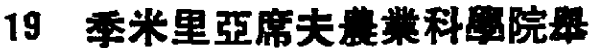 行紀念會議}

1950年12月6日，莫斯科季米里亞布夫農業科學院

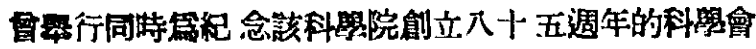
䉝。

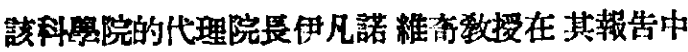
然出有趣的数字：十月革命前五十二年間,該科學院谟

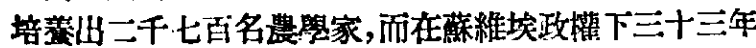
間,就培盖出將近一萬二千五百名農蛔家。現在,有三千

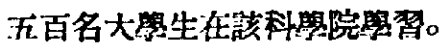

由於其在發展笭業方面的卓越成就，1940年，季米

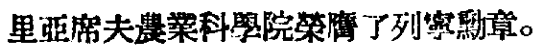

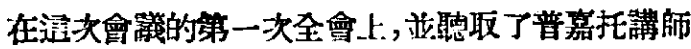

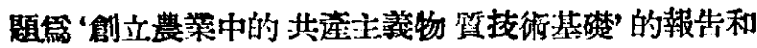

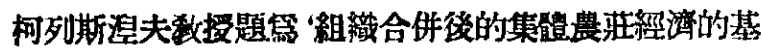
本閒題' 的報告。

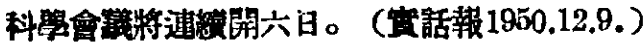

\section{0 斯大林國際和平獎金}

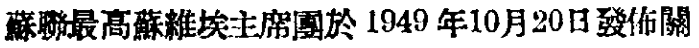
於照立 “加强國際和平” 斯大林國際然金的指命:(一)設

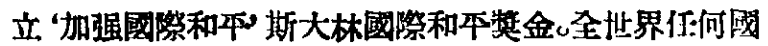
家的公民，凡與戰尔販子裂雪及促進和平有卓越功結

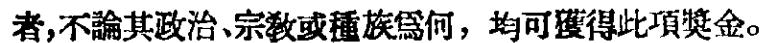

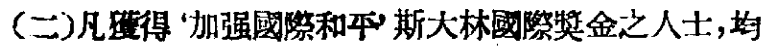
將領到：甲。斯大林國際獎金榮譽獎犾;乙.刻有斯大林

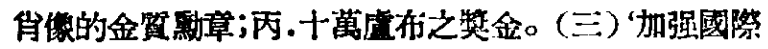

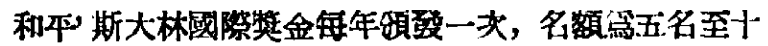

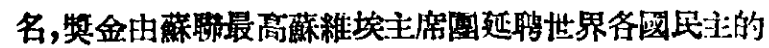

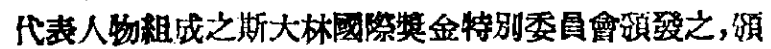

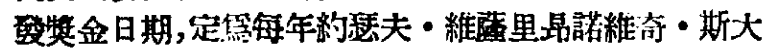

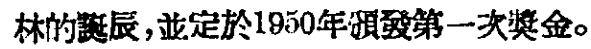

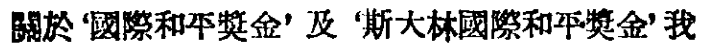
國已成立 “中國作品徽集翆選委員會”，該會發出通知各

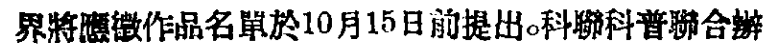
事虎登出通知䊈: 本年度斯大林國烸和平獎金作品定於 12月21日前潠出; 微求聚实推荐1945年以來有间世界和 平的绦出作品或已絓起作用的科學論交。

(科學32卷11期)

\section{1 由宇宙緗所得到的兩個大型 的似星的亮點}

1949年夏天，法國物理照家 Leprince-Ringuet 等四 人，晢以三萬公尺的高度，用 Ilf ord G5感光板來觀测，

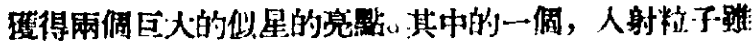

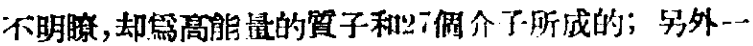

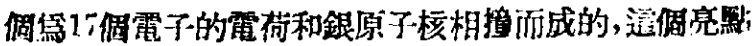

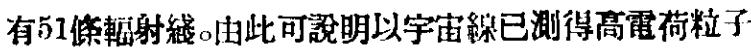

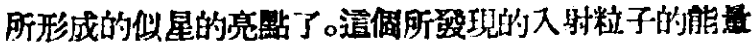

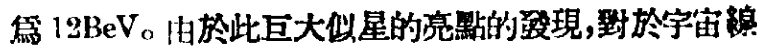
起源, 可得到進一步的研究。( 物理學钎論' No.1273)

\section{2 娄中子的骤現}

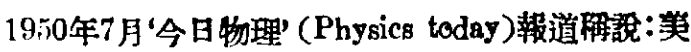

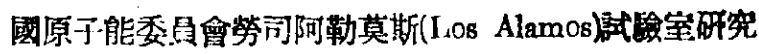

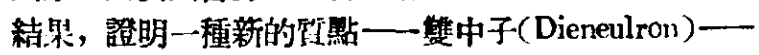

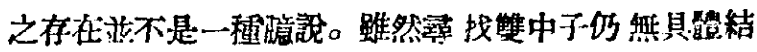

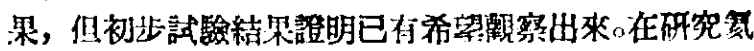

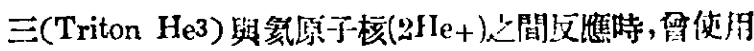

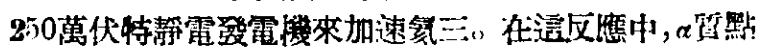

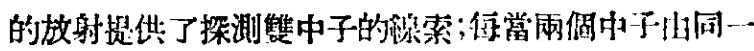

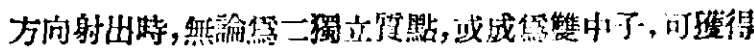

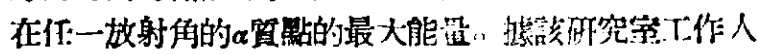

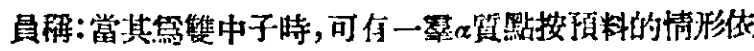

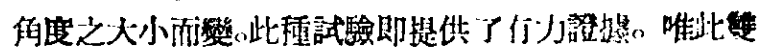

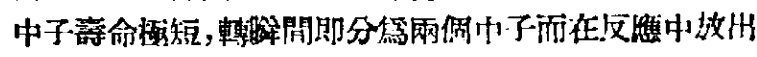
能量。

( 發瑟" 1950 年9月㩆)

\section{3 介子的筫量}

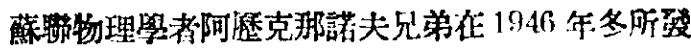

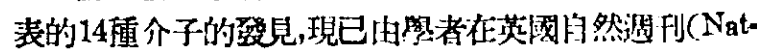

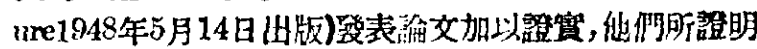
的介子的算量 $110 ; 140 ; 200 ; 250 ; 300 ; 350 ; 450 ; 550$; $680 ; 850 ; 1000 ; 1300 ; 3800 ; 8000 ; 2.1000$ 等種。(單位焦 電子質量)

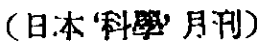

\section{4 最近低溫物理學的研究}

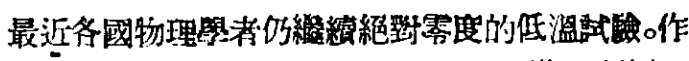

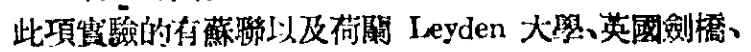

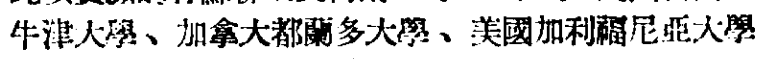

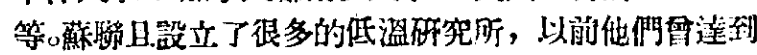

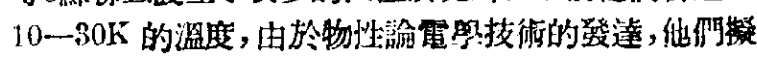
澾到 10-60K 的超低溫的程度，流個保理是证自旋的 訊簽中將結晶的能階 (Energy lever) 的軖移與核约共 鳴而發生了超短波,而引起了低温作用。最近閣於氛的

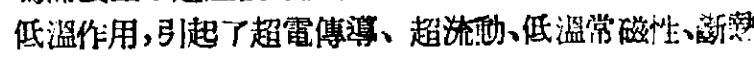
底磁等的研究。如理諭物理學者 Born, Iondon, Hein senberg通類研究最焦活躍。

(日本科影?月刊)

\section{5 古代鑽孔石頭}

關於占德文(Goodwin) 最近發表的一封估 “南非不i

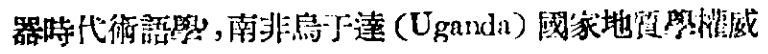

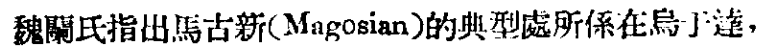
而不是在根倍(Kenya)地方。

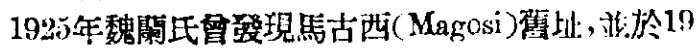

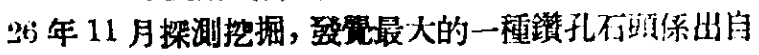


二圭四英尺厚的地既中，在賞時那是顶古老的一種。

1949年11月，魏闌氏在布拉瓦約 (Bulawayo) 地方 國家博物舘重文看到在南汝德酒咂所發現之鑽孔不咟，

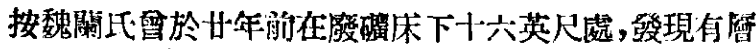

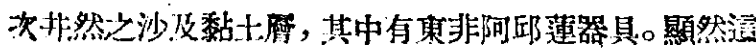

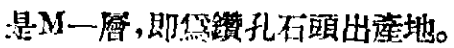

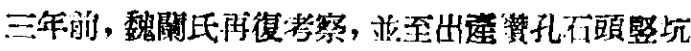

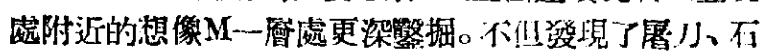
斧度基他阿邱連型器具，更嗫現有兩塊平的、人陪的石

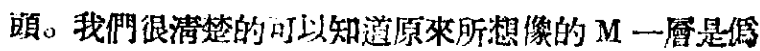

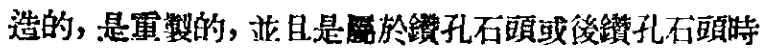
代。

('自然No.4”24)

\section{6 新維他命之墢現}

在美國化學協會第 117 屆全國會燨中,塔克斯大學 沙夫效授發表了維他命 B新族的發現,新族可以抵抗等

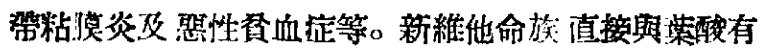

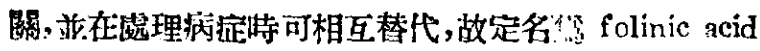

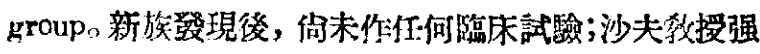

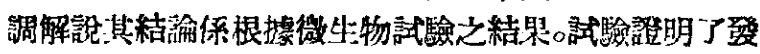

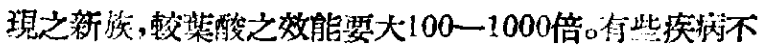
诣认禁酸然療的，可用 folinc acid group 治好。牛肝中 富有大量folinic acid. (“發現”1950年9月號)

\section{7 細菌的間接分裂}

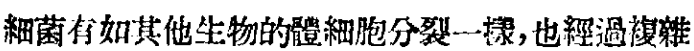
的間接分裂過程。在里約欮內盧召開的第，五国國際微生

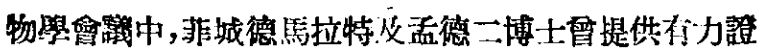
據，閐述細菌之間接分裂。然而現在還不能預測狺種發

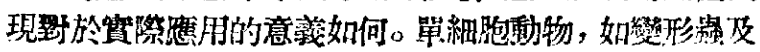
草展䙌，是潐行間接分裂的闹特較大植物和動物的細 胞也淮行間接分裂。但是直到琴在單細胞植物還汶有逼 種現保，僅提最近幾年科學家才確定甚至細菌內也有 細胞枢的存在。

韭城科學家們兽在微生物巨桿菌的細胞核中,觀察

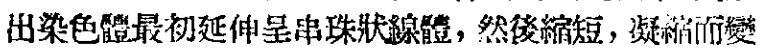

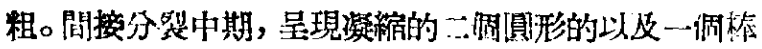
狀的,一共三條染色體。以挠復呈束珠狀。

包括烌結方法來染色或国定細菌細胞的新技微, 使 科學家能够看到染色體, 以及在其間接分裂過程中的狀 蔇。

('科學新聞'58突10期)

\section{8 草裏的性激動素}

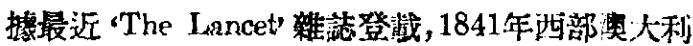

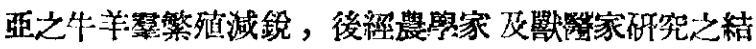

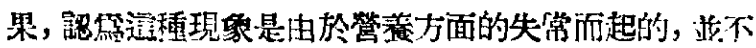

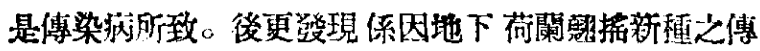

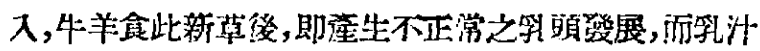

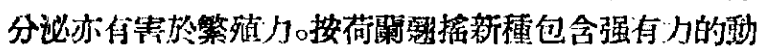

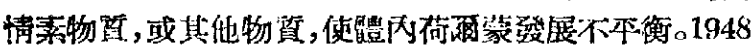

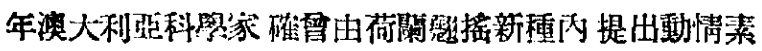

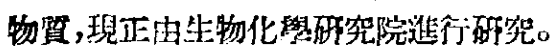

(“發僛1950年9月號)

\section{9 換血}

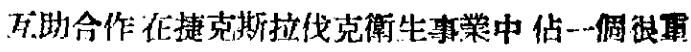
要的地位，許多解程繁整虎理的基本力法之短影片，起 了交流經驗的作朋，例如最近所採影片之一就談到了是 兒健康中 $\mathrm{R}_{\mathrm{h}}$ 因等諸問題。

按大部份人的血液中柈有Rh因䇣，很少人的血液

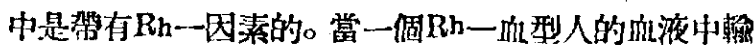

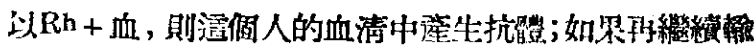
以 $R h+$ 血，則血液凝固，血液循環受阻、Rh因傷是可以 選傅的,嘗母親是 $\mathrm{Rh}+$ 血型, 父親是 $\mathrm{Rh}$ - 血型, 他們第

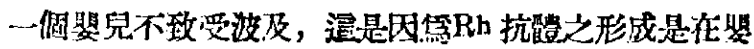

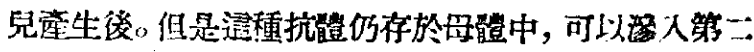
個或以下㮩兒的血液中。

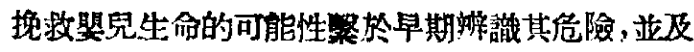
時替換照兒之向液。

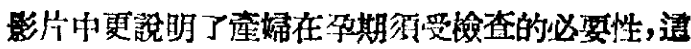

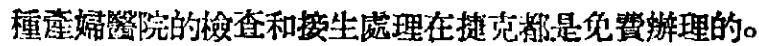
（掟克生活・1950年10月號）

\section{0 鋼內命碳的微量分析法}

用改淮的電薄定是法Conductometric Method 分析 銓內所含微量的碳( $0.03 \%$ 以下)，結染可達0.0005\%(

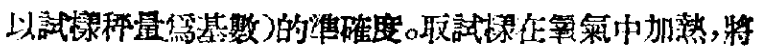
生成的 $\mathrm{CO}_{2}$ 吸收於 50c.c. 含 1g. 的 $\mathrm{B}_{2}(\mathrm{OH})_{2} .8 \mathrm{H}_{2} \mathrm{O}$ 伎

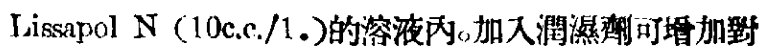

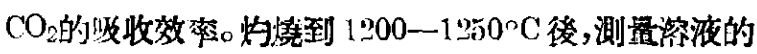

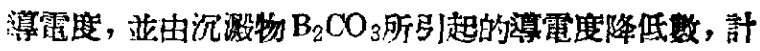
算碳的百分等。

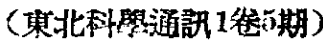

\section{1 直接染料在棉毛織物混染做 内之着色}

直接染料多拉左紅(Durazol Red 2 B) 在 $40^{\circ} \mathrm{C}$. 溫度 下對棉織物的附着力最强，在更煦温度下可更块地被吸

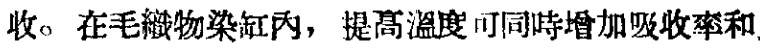
染料的被吸收量。在染酒內加人艺确，以及變更染液影

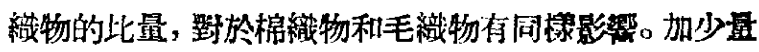

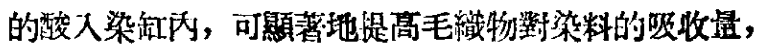

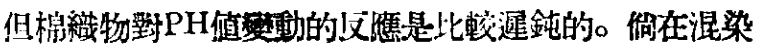

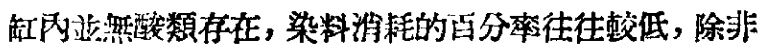
我們使用的染料是少最的。在通诗垁—一在少用染料的 時侯，兩種織物念份同量的染料，因此它們的緎維色澤 是深淺一致的。增高染料量或增高緎維用量之後, 棉蟣 物必須吸收更多的染料，方可與毛䄳物的色澤配合。最

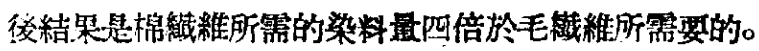

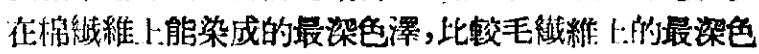
涬相遠很遠。

（東北科县通訊 1 发，期）

\section{2 松榯整紙䧳法}

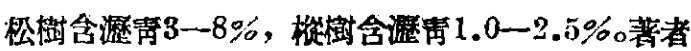

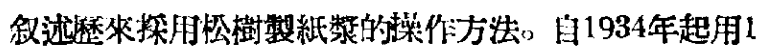

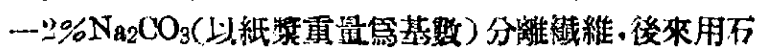




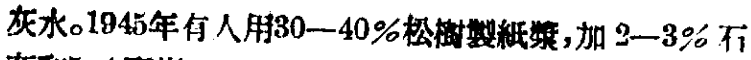

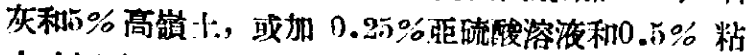

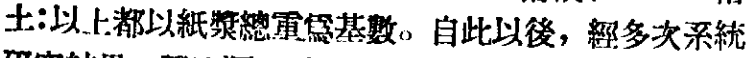

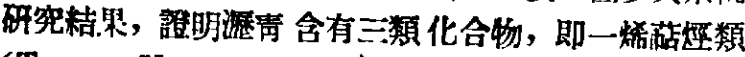
(Terpene Hydrocarbons)、海松脂酸 (Primaric Acid)、 松油酸 (Pinic Acid), 和脂肪酸的甘油脂類。在分離䋐維

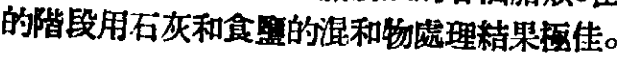

（東北科姐通訊1管5期）

\section{3 在紙故内以石蠋代松香上膠}

因松香跬紙的性㾞有害，再則松香來源不多，所以

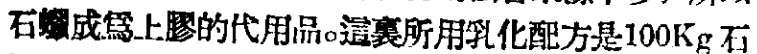

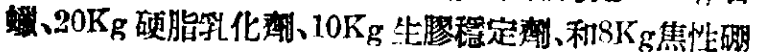

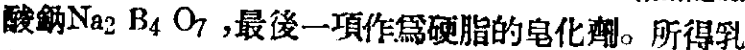

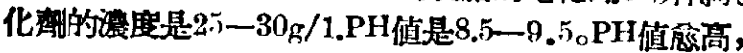

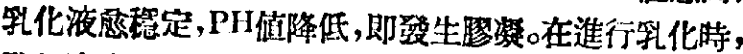

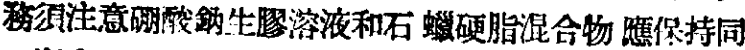

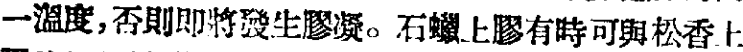

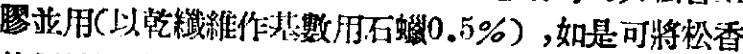
使用量䦽減四倍(由2.0淢至0.5\%)

(果北科罢通訊 1

\section{4 除草割}

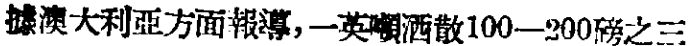

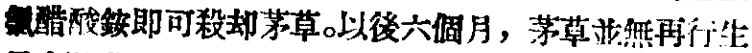
長之跡䨋。

(“锩現'1950年10月號)

\section{5 羅馬尼亞建築巨大水電站}

在比斯特里查河盆地,特建策一個具佮一十一蕰基

国特威力的羅馬尼亞梘模最大的水電站。

由於比斯特里查河塻堤的敒策，而形成 j。周能突

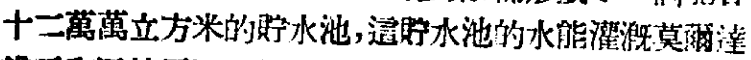

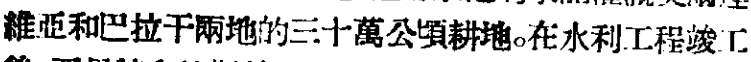

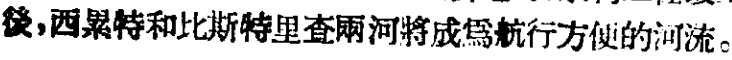

（菑話䇉1950.12.10.）

\section{6 保加利亞的水利建設}

保加利亞的水利连役，在最近五年中，水利灌激遗

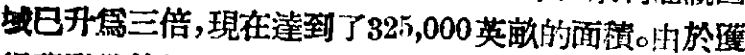

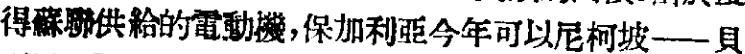
列尼(Nikopol-Belene)和斯維什托夫(Svishtov)低地的整

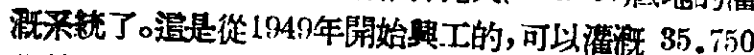
英矿的田地。在 1950 年初,會出野更多的電勒機, 更多的

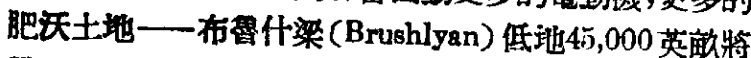
要得陮溉。

("自由保加利哇”)

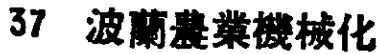

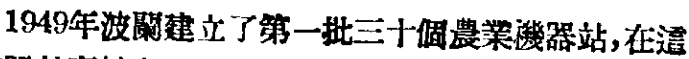

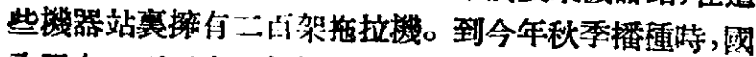

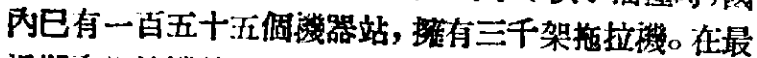

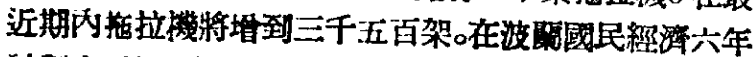

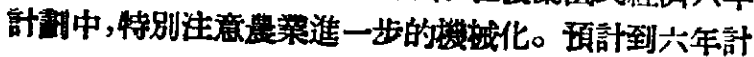

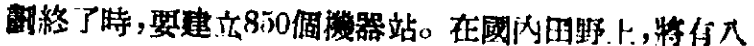

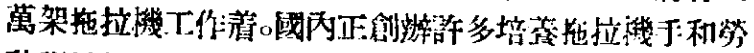

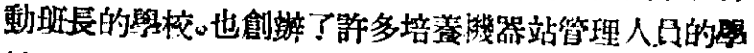
校。

（身北農業No.20）

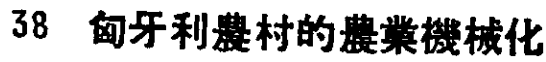

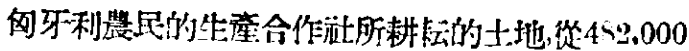

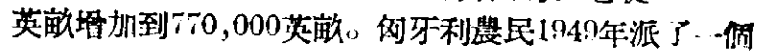

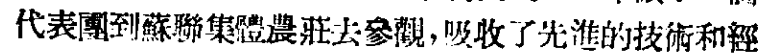

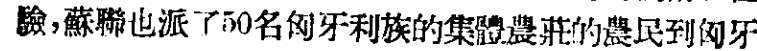

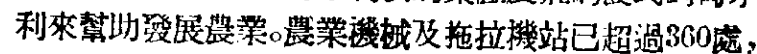

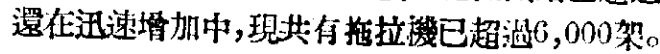

\section{(匈牙利新閩)}

\section{9 保加利亞哏村電影化}

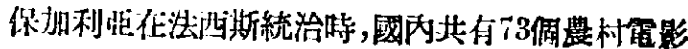
站,而現在已存4.77储村䥓電影化了。

流的的電影站也得到了巨大的發展，這種電影站從

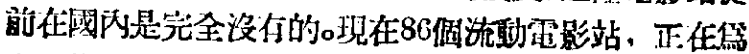

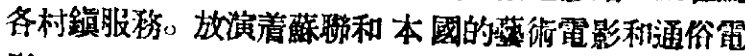
影。

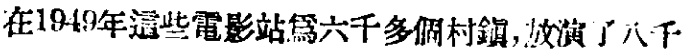

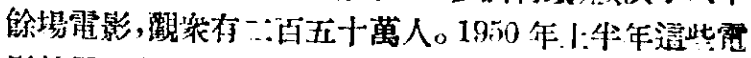
影站琶4,769估村鎮,放演了5,900場電影。

(果北㖘檏)

\section{0 羅馬尼亞建立集體農莊一週年}

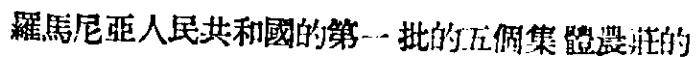

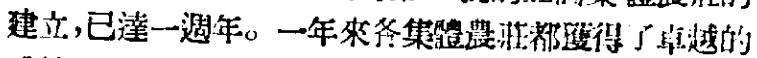

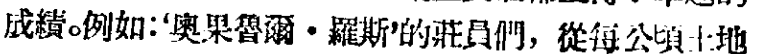

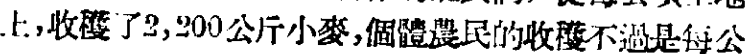
頃810公厅。特拉克多維爾・維斯, 農性達到了更大的成 就，他們的收段是住公頃2,800公厅。

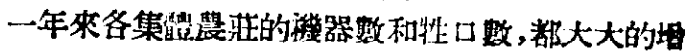
加了，倉庫、馬兓、猪湀等也都建策迅來了。電力已留泛 的被用在日常生活中。

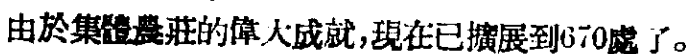
（東北整業No.20）

\section{1 勾京將数設地道車}

1938年匈京有達佩斯德的雷車乘客平均每月第90， 852,000 人, 1950 年濖数目已塻達50,8:3, $000 c 1988$ 年公 共汽車乘容平均每月3,179,000人, 19\%华增至 7,38 ,

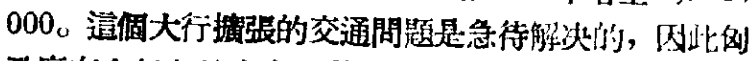

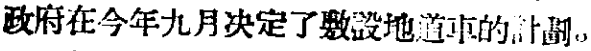

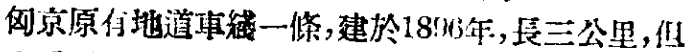

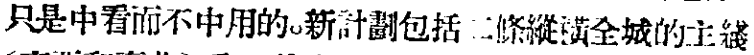

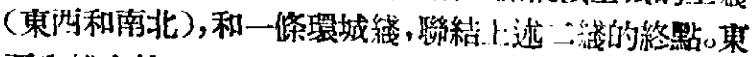
西全綫定於1955年完成。建策.L程密要一萬名工人,十 一萬五千顿的鐵料和十五萬顿的水泥。

（朱榮昭） 


\section{2 國際細胞學標本之收集}

论域際生物照聯合協助之下，國際細胞罢摽本已收 集任比利時盧芳地力之卡墸研究院，收集之標本由該院

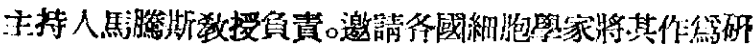

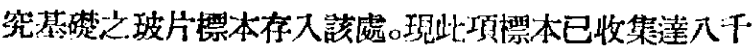

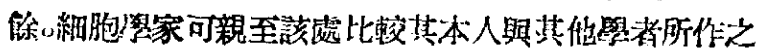
砛究。存入該庞之標本，可以隨特取回。

('自然'No.4223)

\section{3 波蔽科學院}

波钧科學院第 19 期年间已經出版，每篇文字均附

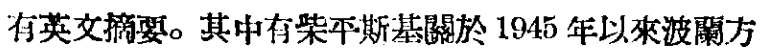

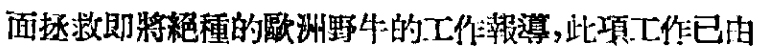

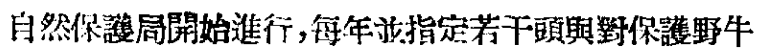

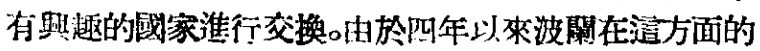
活動, 現在萑聯已有四個湆殖站, 討麥办有一荃殖站。

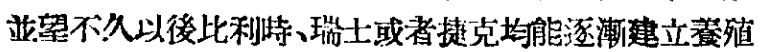
站。年刊䏌包括高斯巴關於北極方面自然保濩問題; 華

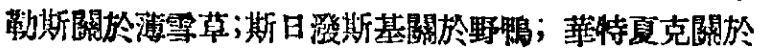

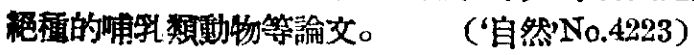

\section{4 波蘭克拉克地方之工程度校}

工程夜校開罢典禮已在波闌克拉克 (Cracon)地方

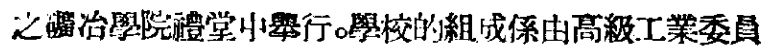

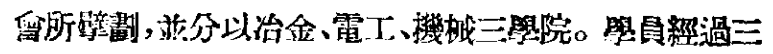

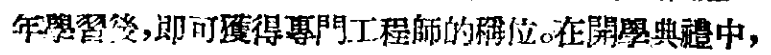

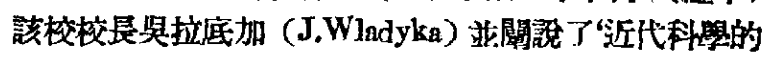
唯物证痖。

(“波闌新聞”)

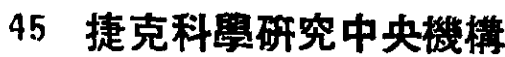

在布拉格捷克國家計部局內, 最近成立一科學研究

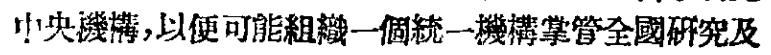

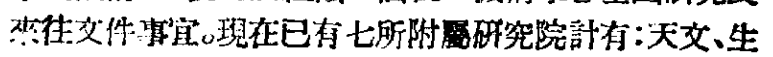
物、物理、地貆、化學、數學及偏蛋光學等研究所。

個別研究院之括究結果是用來促速改善國民經看，

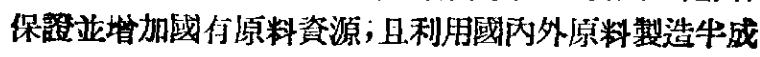
品及成品，以達到增加生產，防止絰濟摃失的目的。

傅卡克博士被潠筒中央委員會主席。斯洛伐克地方 科學研究中心站已在布拉带斯拉瓦成立。

(“布拉格新聞”6卷15期)

\section{6 捷克成立偏極光學研究所}

揵克数授海羅岛斯基 (Herovsky) 發明了偏極光學 (Polarography) 至今已有二十七七年了。这個方法對於電

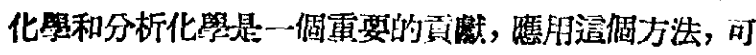
收检定出溶液中桠微量 (可少至十萢萬行之一克) 的然

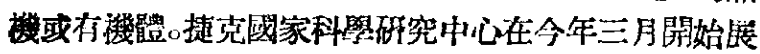

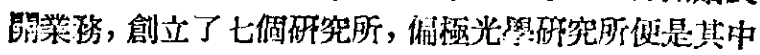

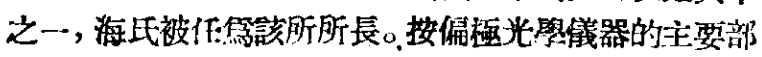

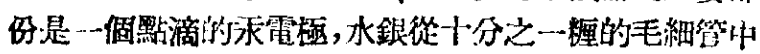

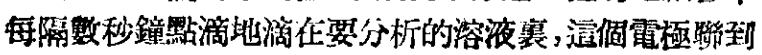

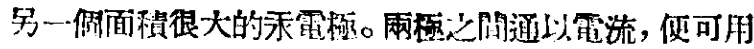
自動紀錄器訅下霍流强度與電位.差二者之䦌督換的閶 係，如此可以得到一組曲路，代表所要分析物品的特性。 海地的學生 Petr Euman 用逜方法淮行植物中維他命 丙的分析和研究，得到卢超的成績。1951年正月任揵宗 普拉格將要舉行一個國際偏梅光學會㬢,將要標誌出海 数授逭一登明的價値。

(朱榮昭)

\section{7 捷克新設兩所高等學校}

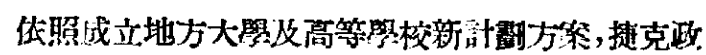

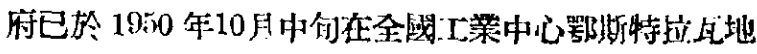

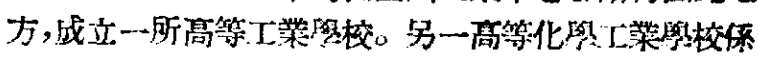

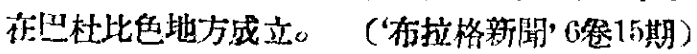

\section{8 日本生物害家幛相研究米邱 林、李菻科悬說}

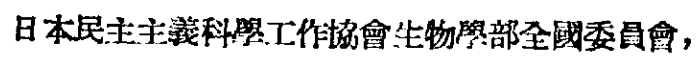

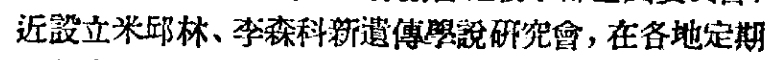

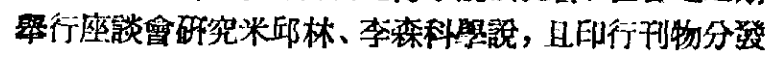
全國各地,引起全國生物學家演泛的研究和試驗。

(日本“科照者”No.28)

\section{9 '科学與动全' 季刊}

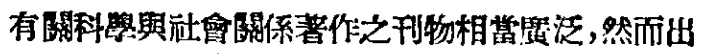
刊相賞零散且不易㨦得。故聯合國交郄組已發行了第一

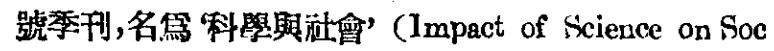
iety), 內容包括有人名鍬及有關資料之摘要等。

( “愣, 1950年9月號)

\section{0 日本東北大學之 ‘科學啹告’}

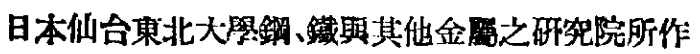
之的究工作程常刊登於該校出版物之 “科學啹告” 中。目 從1944年第32卷出版以後, 該刊即末间出版。最近已分 焉三組復刊，第一組專門刊登該校碈究院關於物理、化

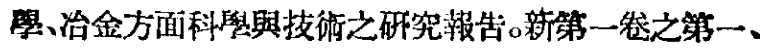
二雨期, 已於1949年5月及8月出版。

( '自然 No.4223)

\section{1 北牛球泠溫带乘培木本植物

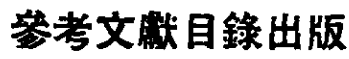

影書原文名稱篬 Bibliography of Cultivated Trees and Shrubs hardy in the cooler Temperate Region of Northern Hemisphere, 於1949年由哈佛大學阿請德植

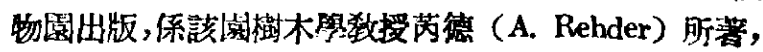
此甾出版不久，荫德敎授即逝壮，草年85戴。此書共 825

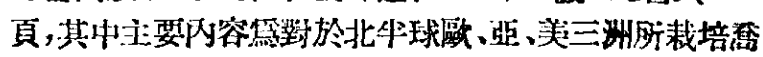

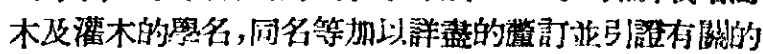

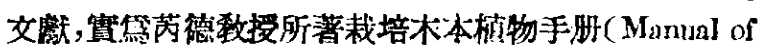
Cultivated Trees and Shrubs) 一書補充的搌大交

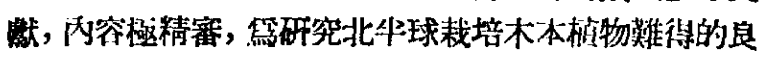
好灰。

(中國植物學雜誌5想 1 期)
第-..期
科學通越
$\cdot 113$. 


\section{2 科悬用品可免開稅}

枷合國交数柤已通知其五十九個會員國，傳澾了一-

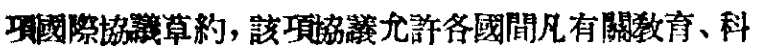

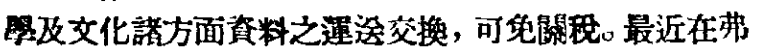

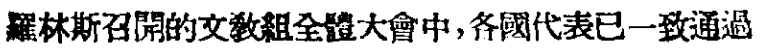

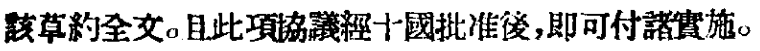

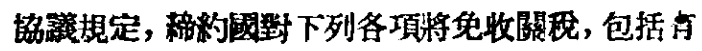

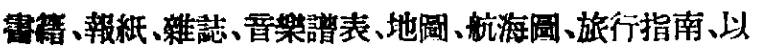

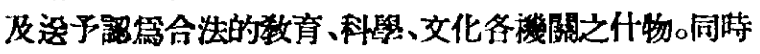

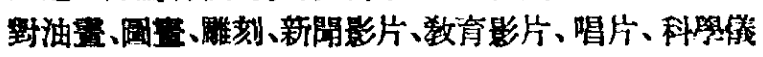

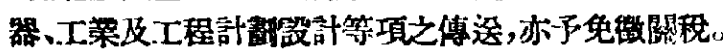

（發現1950年10月號）

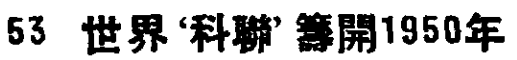 度第二次大會}

世界 '科聯” 1950 年度第二次大會预㣁在年底十二 月中在巴黎罢行, 但目前國際局勢㡉好莫测, 故是否能 順利如期在巴黎開會，現在無從確定。法政府第签 Vira

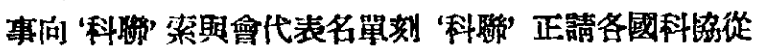
速將名單通知 “科胎”。

（留英中國科協特輯1950.10.20.)

\section{4 留英中國科協1950年第二次 全筑大會}

留英中國科坫 1950 年第二头全镜大會於 7 月 18 日 假留英学生會年會會址一一伯明罕西山學䟚一舉行。到

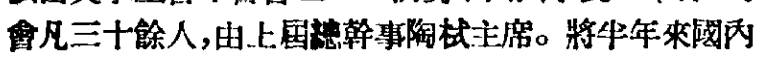

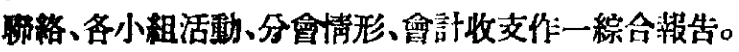
其头决㿥幹事會提請策案三件，最後以 “分會” 幹事大多 返國在即提請大會改選新幹事會，访决定因會員人数減

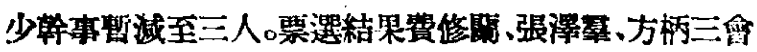
貣裳選。會後由中部交會水菓茶點招待全能與會會友盡 散散。

（留英中國科協特輯1950.10.20.）

\section{5 中國留日學生自然科學協合}

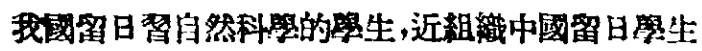
自然科照㙝會，總會會址钤在果京都交京踶小石川一町 目一番地。

(掘)

\section{6 留法中國科學工作者協會}

中國科登工作都咕會法國分會，已改䊈爲留法中國

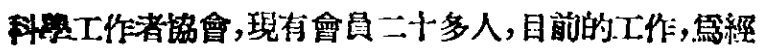

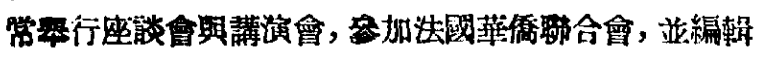
其“僑整? 刊物。

\section{7 日本民主主巷科學工作者協 合㦛行第五次全㖨大合}

推有一萬以、的會虽與一百倜文部的日，本民主主

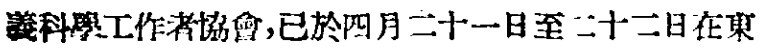
京法政大降舉行全四代表大會，到會的有日本全國冬地 著名科學家、科學技衔人員等代表一百五十余名，會議

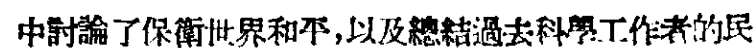

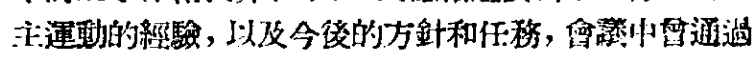

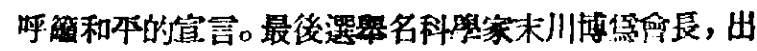

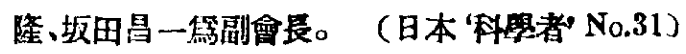

\section{8 波荿科學工作者委員會的决 鿁}

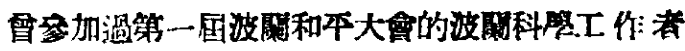

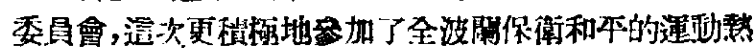

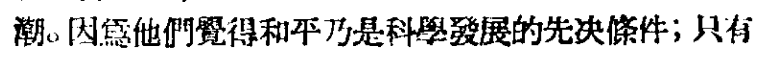

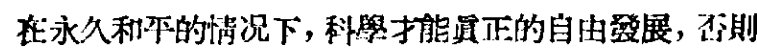

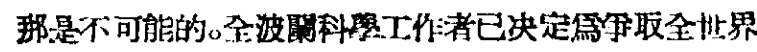

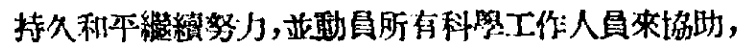
促淇早日成功。他們並保管嘗了加强本國及全世界和平

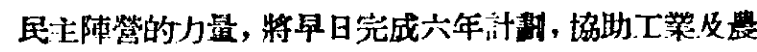

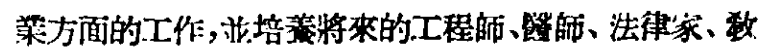
師以及科學傢等而努力。（'波閎新聞” No.18)

\section{9 捷克植物學合}

該會大戰㓩出版的年報 ‘Preslis'因戰事停刊，其 第23-24期 (1943-1947)已於1948年恢復出版, 其 中有取消下列三人會員資格的路明：(1)克拉錫內博上 (Dr.V. Krajina), 查理大悬 (Charles University) 植

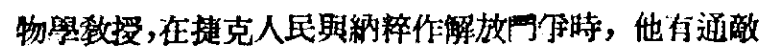
具陷害革命志士的罪幛。(2)多明博士 (Dr. K. Domin)

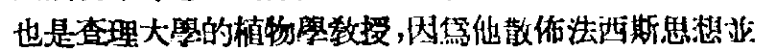

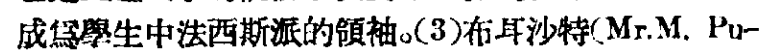
lchart) 是多明博士的親信。(中國植物學雜誌万管 1 期)

\section{0 布拉格衛生工作者會䛨}

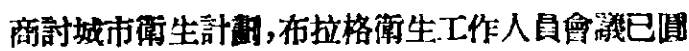

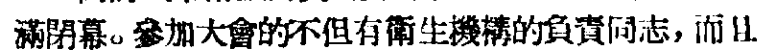
非衙生工作人員也提供了建設性的意見;他們们括有嫌

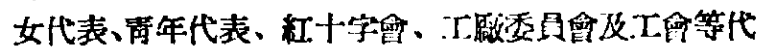

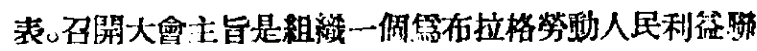

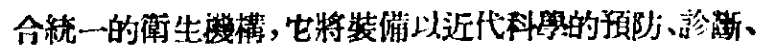

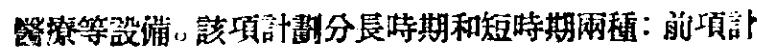

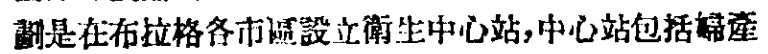

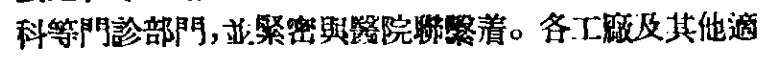
宜地方成立附設站，以便工人隨洔可在現䝮登撩。哣期

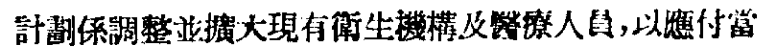
解之需要。

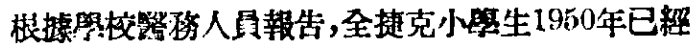

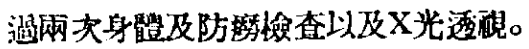

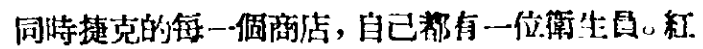

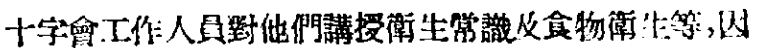

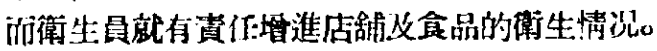

(布拉格新聞6 16 期)

\section{1 所謂太平洋學令令䜋}

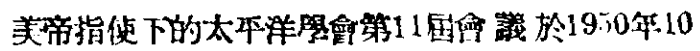

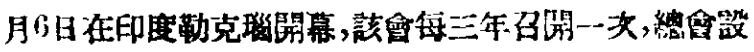




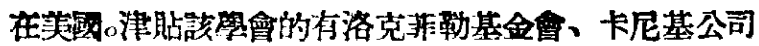
和蓄意控取亞洲国家和太平洋國家的天然資源的 美國 大工染家們。太平洋學會的領袖們按照美國國稀院的命

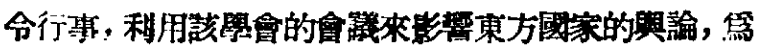

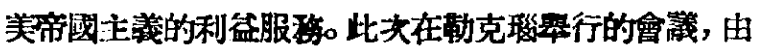
太平洋學會太平洋委員會(垛行被構)秘書長、美國的霍

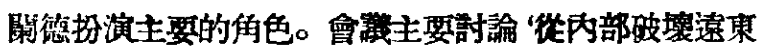
和实南互國家的民族解放運㿞的方法，和利用所謂“民

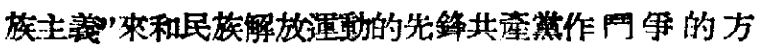

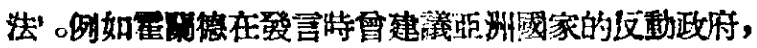

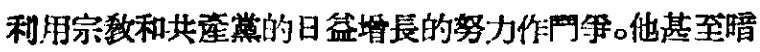
示:最好激請“有經驗的行政人員” (換句話馀，就是美國

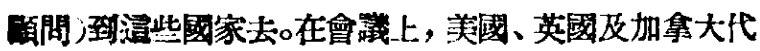

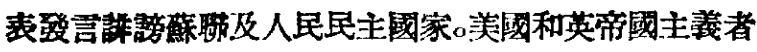
的使者企圆强泊亞洲代表接受这㮔思想，就是: 英美在

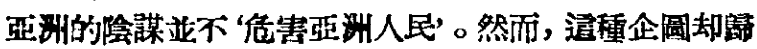
於失敗了。巴基斯坦的代表宣稳: 美國在太平洋和遠果

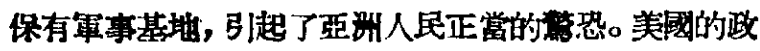

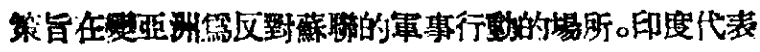

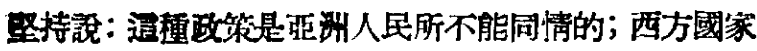
块地取消在亞洲的殖民地。（科學32怣16期）

\section{2 國隆分析化盟全鿁定1952年 是行}

國際分析化學居議, 定1952年9月4日，將佂英國牛 津大學舉行。

( '自然No.4224)

\section{3 國際“分析化學日”在巴黎}

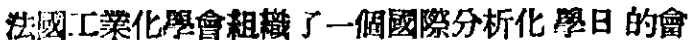

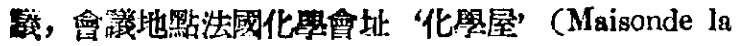
Chimie),特閂1950年11月18日至24日。

會程中有一百篇以上的渝交的宣讓，如甘德( (Gand)

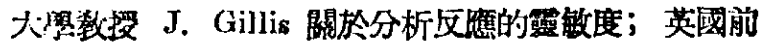
湋尘部分析處長 M. G. W. Monnier-Williams 關於食 品分析; 法國原子能委虽會原料處長 M. Guéron 關於

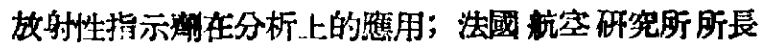

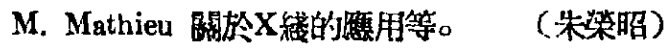

\section{4 捷查理士大學自然科學院學 生致函燕大學生對我國人民 抗美援朝正恙行動致敬}

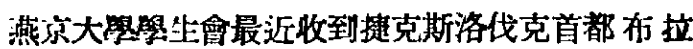
格查理土大學自然科㭷院全姐同照的签名函件，對我國

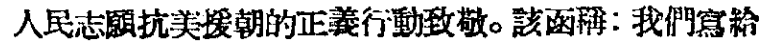
你門的望封信，代表着我國的青年、工人、農民以及所有 進步人民的感情。你們的閶采就是我們的网争，你們英

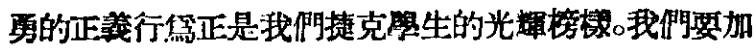

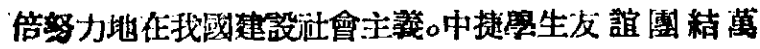
娄! 中朝人民勝利㵧歳！（新華茫稿1950.12。19.)

\section{5 奥立节教授斥原子㽞非法}

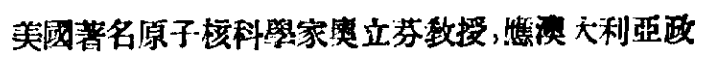

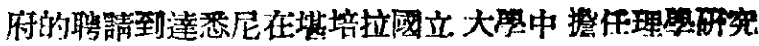

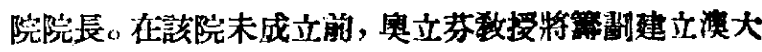

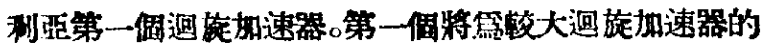

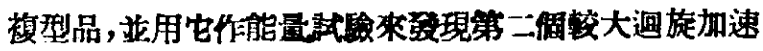

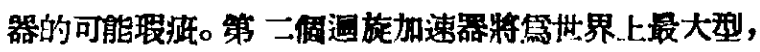
㩲有200,000,000伏特能量。他在网得雷德地方諰: 原子 彈是 ‘非常不正當而又非營不可靠的殺人方 法。' 他镜: 原子彈只能被用來恫蔽平民們，便用原子彈在道德上是 不正當的。

( '球現' 1950年10月號)

\section{6 西德英團賞局阻止約里奥・ 居里逼㫩返國}

世界保得和平委員會主席、失國著名科基家的里 奥・居里敎摱，於去年11月23日由華沙返國途中道程眖

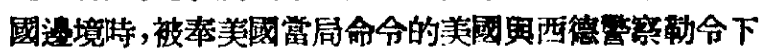

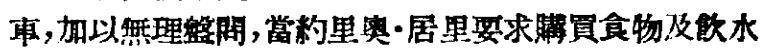
時,美國警察故意二奞，限他用美元去換馬克，而不能用 英镑或法郎去換，結果使他不得的食。䄪里奥・居里踓然

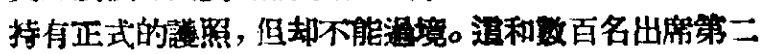

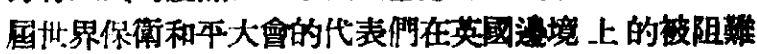

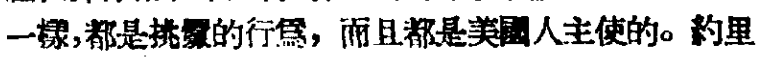

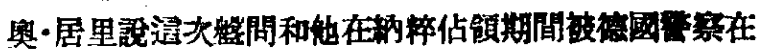

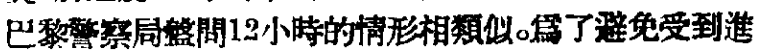
一步的侮层和迫待，他被迫回到布拉格。

(新華社稿1950.11.28.)

\section{7 荷䈀當局建捕進步焉者}

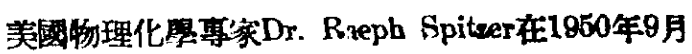

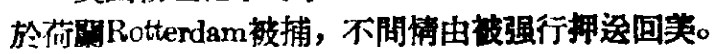
（留英中國科協特蜡1950.10.20.)

\section{8 美帝研究殺人法}

美國政府不僅反對禁止原子武器，並且臬背整用化

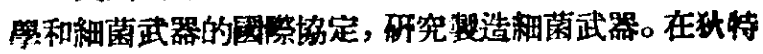

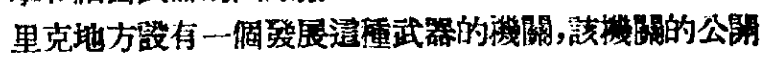

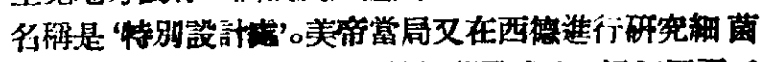

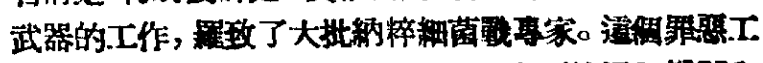

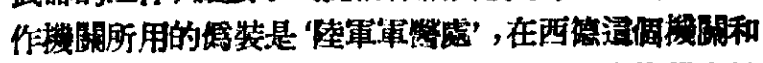

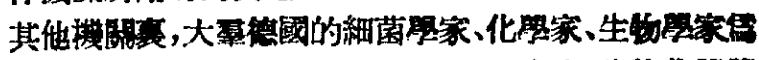

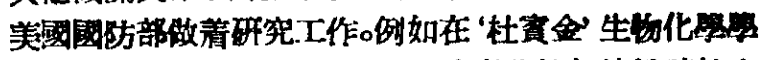

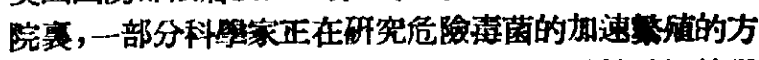

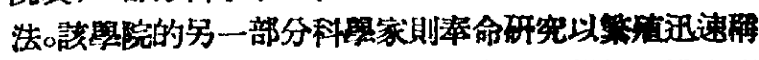

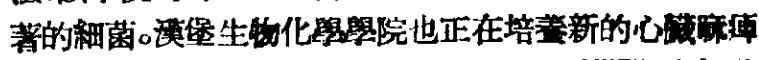
成。在美帝指使下，加全大也設立了七個專門研究緗菌 武器的璂酸筀。

(新诗代)

$$
\text { 第一期 }
$$

科學通银 $\cdot 116$ • 